Joanna Szypniewska

Uniwersytet Gdański

szypniewskajoanna@gmail.com

\title{
Klauzula zasad współżycia społecznego w umowie o obsługę prawną - glosa do wyroku Sądu Najwyższego z dnia 19 czerwca 2015 r., IV CSK 590/14
}

DOI: http://dx.doi.org/10.12775/SIT.2017.043

„Zastrzeżenie w umowie o obsługę prawną odszkodowania dla radcy prawnego za zobowiązanie się do postępowania po ustaniu obowiązywania tej umowy zgodnie $z$ ustawowym obowiązkiem zachowania w tajemnicy wszystkiego, o czym dowiedział się on w związku z udzieleniem pomocy prawnej, jest sprzeczne $z$ zasadami współżycia społecznego i tym samym nieważne (58 § 2)”.

\section{Wprowadzenie}

Przyznać trzeba, że klauzula zasad współżycia społecznego jest ze swej natury nieostra, stąd wymaga każdorazowego skrupulatnego rozpatrzenia w kontekście konkretnego przypadku. Zakres czynności sprzecznych $z$ zasadami współżycia społecznego jest zatem nieokreślony i zmienny, tak jak zmienne jest środowisko społeczne, w którym czynności prawne, a następnie ich ocena aksjologiczna są 
dokonywane ${ }^{1}$. To konsekwentnie tworzy złożoność tej problematyki, co powoduje, że nie schodzi ona $z$ wokand sądowych. Jak stwierdził $\mathrm{SN}^{2}$, jest to „Zagadnienie kontekstu faktycznego, tj. okoliczności konkretnego wypadku, i jakakolwiek próba uogólnień adekwatnych do każdej sytuacji z góry byłaby skazana na niepowodzenie”. Glosowany wyrok może stanowić kanwę do snucia rozważań na temat tej trudnej materii, której aktualność jest nieustannie odnawiana.

Stan faktyczny raz ustalony przez sąd I instancji został przyjęty bez zastrzeżeń przez sąd apelacyjny. Bezspornie wynikało $z$ niego, że dnia 2 października 2006 r. pozwana spółka zawarła $z$ kancelarią powodów - radców prawnych umowę o stałą obsługę prawną. Dnia 20 marca 2008 r. wprowadzono do niej klauzulę „o zakazie konkurencji i lojalności”. Powodowie zobowiązali się w niej nie prowadzić przez 12 miesięcy po ustaniu obowiązywania umowy działalności konkurencyjnej w stosunku do statutowej działalności pozwanej spółki. Za działalność konkurencyjną rozumianą bardzo szeroko uznano m.in. wykonywanie wszelkich czynności w ramach stosunku pracy lub jakiegokolwiek innego stosunku prawnego na rzecz jakichkolwiek polskich i zagranicznych podmiotów konkurencyjnych względem pozwanej spółki oraz występowanie w charakterze pełnomocników lub agentów tych podmiotów. Ponadto powodowie zobowiązali się do zachowania w tajemnicy wszelkich uzyskanych w związku z wykonywaniem obsługi prawnej poufnych informacji, których ujawnienie mogłoby narazić spółkę na szkodę. Zastrzeżono także odszkodowanie dla powodów od pozwanej spółki za okres trwania zakazu konkurencji w wysokości 80\% umówionego wynagrodzenia. Następnie, dnia 28 maja 2008 r. pozwana spółka wypowiedziała powodom umowę zawartą $z$ nimi w dniu 2 października 2006 r. z zachowaniem trzymiesięcznego okresu wypowiedzenia, uiszczając wynagrodzenie także za ten okres, odmawiając natomiast

${ }^{1}$ P. Księżak, Art. 58, w: Kodeks cywilny. Komentarz. Część ogólna, red. P. Księżak, M. Pyziak-Szafnicka, Warszawa 2014, https://sip.lex.pl/\#/komentarz/587250165/170694 (dostęp: 17.07.2017 r.).

${ }^{2}$ Uchwała SN z dnia 29 września 1987 r., III CZP 51/87, „Orzecznictwo Sądu Najwyższego. Izba Cywilna” 1989, nr 1, poz. 14. 
zapłaty odszkodowania zastrzeżonego za umowny zakaz konkurencji. Skierowała do powodów pismo o uchyleniu się od skutków prawnych złożonego pod wpływem błędu oświadczenia woli przy podpisywaniu tej dodatkowej części umowy, podnosząc, że radców prawnych obowiązuje ustawowy zakaz konkurencji, zatem klauzula ta nie miała uzasadnienia.

Radcowie prawni skierowali więc pozew przeciwko spółce o zasądzenie na ich rzecz odszkodowania za powstrzymywanie się od prowadzenia działalności konkurencyjnej w stosunku do pozwanej spółki zastrzeżone w zawartej z nią umowie. Zarówno sąd okręgowy, jak i sąd apelacyjny uznały, że klauzula o zakazie konkurencji i lojalności nie była nieważna $z$ powodu sprzeczności $z$ zasadami współżycia społecznego, jak też, że nie doszło do skutecznego uchylenia się od skutków prawnych przez spółkę. W skardze kasacyjnej pozwana przytoczyła jako podstawę naruszenie przez sąd apelacyjny art. $58 \S 2$ k.c. ${ }^{3}$ oraz wniosła o uchylenie i zmianę zaskarżonego wyroku w całości.

Sąd Najwyższy po rozpoznaniu uchylił zaskarżony wyrok, zmienił wyrok sądu okręgowego w ten sposób, że oddalił powództwo oraz apelację powoda i obciążył go kosztami postępowania w sprawie. Warto prześledzić kolejne etapy rozumowania, które doprowadziły do takiego rozstrzygnięcia.

\section{Radca prawny jako zawód zaufania publicznego}

Punktem wyjścia rozważań Sądu Najwyższego jest zaliczenie zawodu radcy prawnego do zawodów zaufania publicznego w rozumieniu art. 17 ust. 1 Konstytucji Rzeczypospolitej oraz wskazanie, że obowiązek radcy prawnego zachowania w tajemnicy wszystkiego, o czym dowiedział się w związku z udzielaniem pomocy prawnej, jest nieograniczony w czasie i nie można go z niego zwolnić. Sąd Najwyż-

${ }^{3}$ Ustawa z dnia 23 kwietnia 1964 r. Kodeks Cywilny, Dz.U. z 2017 r., poz. 459 ze zm., dalej: k.c. 
szy podzielił stanowisko Trybunału Konstytucyjnego ${ }^{4}$ określające ów obowiązek jako nierozerwalnie związany ze statusem zawodu radcy prawnego, stwierdzając, że zachowanie poufności jest nieodzowne do prawidłowego wykonania zleconej usługi, co leży w interesie nie tylko klientów, ale i samorządu radcowskiego oraz wymiaru sprawiedliwości. Zgodnie $\mathrm{z}$ twierdzeniami zawartymi w uzasadnieniu powodowie byli zobowiązani do zachowania w tajemnicy wszystkich uzyskanych informacji w związku $z$ wykonywaniem obsługi prawnej spółki już na podstawie przepisów ustawy o radcach prawnych ${ }^{5}$ oraz Kodeksu etyki radcy prawnego ${ }^{6}$. Określono więc poczynioną przez strony klauzulę jako $\mathrm{w}$ istocie zbędną, skoro przewidzianą przez ustawodawcę. Zdaniem Sądu Najwyższego odszkodowanie stanowiłoby wynagrodzenie za zaniechanie, do którego powodowie byli zobowiązani już z mocy ustawy, zatem zastrzeżenie to należało uznać za pozostające w sprzeczności z zasadami współżycia społecznego, a tym samym nieważne. $\mathrm{W}$ przeciwnym bowiem razie radcowie prawni uzyskiwaliby korzyść majątkową z tytułu wypełniania ich ustawowego, a zarazem podstawowego obowiązku łączącego się ściśle $z$ istotą jego zawodu.

Idąc śladem wywodów Sądu Najwyższego, warto poświęcić chwilę przytoczonym argumentom, które doprowadziły do uwzględnienia skargi kasacyjnej. Za uznaniem, że zarzut naruszenia art. 58 $\S 2$ k.c. jest uzasadniony, przemawiał zdaniem SN fakt powielenia treści ustawy i kodeksu etycznego w klauzuli, za której przestrzeganie zastrzeżono wynagrodzenie. Oceny tej nie zmieniło nawet przyznanie, że zakaz świadczenia obsługi prawnej na rzecz innych podmiotów nie mieści się $\mathrm{w}$ gwarantowanym przez ustawodawcę zakresie. Zgodnie $z$ art. 3 ust. 2-5 u.r.p. oraz $z$ art. 15 k.e.r.p. radca prawny jest bowiem obarczony nieograniczonym $\mathrm{w}$ czasie obowiązkiem zachowania tajemnicy zawodowej, z którego nie można

\footnotetext{
${ }^{4}$ Wyrok TK z dnia 22 listopada 2004 r., SK 64/03, „Orzecznictwo Trybunału Konstytucyjnego; zbiór urzędowy, Seria A" 2004, nr 10, poz. 107.

${ }^{5}$ Ustawa z dnia 6 lipca 1982 r. o radcach prawnych, Dz.U. z 2015 r., poz. 507 ze zm., dalej: u.r.p.

${ }^{6}$ Załącznik do uchwały nr 5/2007 VIII Krajowego Zjazdu Radców Prawnych z dnia 10 listopada 2007 r., dalej: k.e.r.p.
} 
go zwolnić. Artykuł 9 k.e.r.p. uznaje ten obowiązek za podstawę zaufania klienta. Stanowi to więc bezwzględny i immanentnie związany $\mathrm{z}$ naturą profesji obowiązek. Tajemnica zawodowa jest istotą zawodu radcy prawnego, gwarantującą prawidłowe jego wykonywanie. Jej znaczenie podkreśla art. 22 ust. 2 k.e.r.p., który nakłada na radcę prawnego obowiązek powstrzymania się od występowania na rzecz nowego klienta, jeśli występuje choćby ryzyko naruszenia zobowiązania do poufności. Katarzyna Mikołajczyk-Graj ${ }^{7}$ uznaje obowiązek zachowania tajemnicy zawodowej za warunek istnienia i funkcjonowania zawodów zaufania publicznego, które wobec oparcia na szczególnej więzi zaufania wymagają istnienia tajemnicy zawodowej jako gwarancji tego zaufania. Podnosi również, iż ma ona charakter formalny, a zatem powstaje $z$ chwilą uzyskania informacji niezależnie od jej treści oraz źródła.

W tym miejscu należy wskazać na znaczne rozbieżności pomiędzy treścią u.r.p. i k.e.r.p. a ustaleniami stron umowy. Po pierwsze, strony umowy odniosły obowiązek tajemnicy tylko do 12 miesięcy następujących po umowie, podczas gdy zgodnie $z$ art. 3 ust. 2-5 u.r.p. oraz art. 15 k.e.r.p. jest on nieograniczony w czasie. Po drugie, według przedmiotowej klauzuli ochrona informacji uzyskanych $\mathrm{w}$ związku $\mathrm{z}$ wykonywaniem obsługi prawnej ograniczała się do zachowania ich w tajemnicy przez radców prawnych. Zgodnie natomiast $z$ art. 12 ust. 3 oraz art. 14 k.e.r.p, obowiązek zachowania tajemnicy zawodowej obejmuje nadto zakaz skorzystania z nich w interesie własnym bądź osoby trzeciej, jak również nakaz możliwie najlepszego zabezpieczenia informacji przed ujawnieniem. Po trzecie, klauzula stron odnosiła się tylko do tych informacji, których ujawnienie mogłoby narazić spółkę na szkodę, podczas gdy art. 12 ust. 1 i 2 k.e.r.p. wskazuje na wszelkie uzyskane przez radcę prawnego informacje, niezależnie także od ich formy lub sposobu utrwalenia. Zakres ustalonej przez strony klauzuli łączy zatem $\mathrm{z}$ zakresem zapewnionym przez u.r.p. i k.e.r.p. stosunek podrzędności, co oznacza, że u.r.p. i k.e.r.p. zawierają regulacje wprowadzone w klauzuli, ale także wykraczają ponad te regulacje.

${ }^{7}$ K. Mikołajczyk-Graj, Tajemnica zawodowa w: Leksykon etyki prawniczej, red. S. Sykuna, P. Skuczyński, Warszawa 2013, s. 391. 
Należy zatem zważyć, że strony dokonały próby ograniczenia zakresu przepisów bezwzględnie obowiązujących.

Zgodnie $z$ art. 58 § 2 k.c. nieważna jest czynność prawna niezgodna $z$ zasadami współżycia społecznego. Ze względu na nieostrość tej klauzuli, jak również daleko idące skutki jej zastosowania podnosi się $e^{8}$ że przepis ten powinien być stosowany powściągliwie. Jakkolwiek sąd ma kompetencję do swobodnej oceny, to niezbędne jest odpowiednie uzasadnienie, dlaczego dana czynność jest niezgodna z zasadami współżycia społecznego.

\section{Klauzula zasad współżycia społecznego}

Nie budzi już wątpliwości, że pod pojęciem zasad współżycia społecznego należy rozumieć podstawowe zasady etycznego i uczciwego postępowania. Pogląd ten wyraził też Sąd Najwyższy ${ }^{9}$. Jest to każdorazowy punkt wyjścia dla rozważań dotyczących tej klauzuli. Fakt, iż radca prawny należy do kręgu zawodów zaufania publicznego, od przedstawicieli których wymaga się wzorowej postawy reprezentującej wyjątkowo stabilny kręgosłup moralny, powoduje zaostrzenie rygoru w stosunku do powodów, którzy zainicjowali dodanie klauzuli do umowy. Radcowie prawni w szczególności stanowić powinni uosobienie zasad etycznego i uczciwego postępowania. Wobec takiej subiektywizacji zasady nawet mniej rażące odchylenie moralne klauzuli umowy byłoby wystarczające do uznania jej za niezgodną z zasadami współżycia społecznego w tym przypadku.

Jak podkreślił Sąd Najwyższy ${ }^{10}$, pozostawienie stronom swobody (na mocy zasady swobody umów $z$ art. 3531 k.c.) nie uchyla kontroli stosunków prawnych pod kątem klauzul ogólnych zabezpieczających obrót gospodarczy przed zjawiskami patologicznymi. Sąd Najwyższy zróżnicował funkcję normatywną zasad współżycia społecznego,

${ }^{8}$ P. Księżak, op. cit.

9 Uchwała SN z dnia 20 grudnia 2012 r., III CZP 84/12, „Orzecznictwo Sądu Najwyższego. Izba Cywilna” 2013, nr 7-8, poz. 83.

10 Wyrok SN z dnia 8 stycznia 2013 r., II CKN 1097/00, „Orzecznictwo Sądu Najwyższego. Izba Cywilna” 2004, nr 4, poz. 55. 
występujących w art. 58 § 2 k.c. oraz art. 3531 k.c., określając pierwszy przypadek jako wyznaczenie granic dopuszczalnej treści czynności prawnej, a drugi jako ustawowe granice swobody kontraktowania. Pogląd ten był następnie powielany ${ }^{11}$. W tym miejscu warto zasygnalizować pewną nieścisłość podstawy prawnej, na której oparł się Sąd w analizowanym wyroku. W doktrynie ${ }^{12}$ podkreśla się, że wobec obecności klauzuli zasad współżycia społecznego zarówno w art. $58 \S 2$ k.c., jak i w art. 3531 k.c. inna jest podstawa prawna uznania za bezwzględnie nieważną umowy obligacyjnej i każdej innej czynności prawnej sprzecznej z zasadami współżycia społecznego. W pierwszym przypadku należy posłużyć się art. 58 § 1 w zw. z art. 3531 k.c., ponieważ sprzeczność z zasadami współżycia społecznego doprowadzi do sprzeczności z art. 3531 k.c., a więc do sprzeczności z ustawą (art. 58 § 1 k.c.). W drugim przypadku natomiast podstawą będzie samodzielnie $58 \S 2$ k.c. W analizowanej sytuacji sąd, przytaczając art. $58 \S 2$ k.c. w odniesieniu do umowy o obsługę prawną, która niewątpliwie należy do umów obligacyjnych, dokonał więc pewnego uproszczenia. Jakkolwiek jest to dość często praktykowane $\mathrm{w}$ orzecznictwie ${ }^{13}$, to warto byłoby wesprzeć skrupulatność wywodu o tę drobną poprawkę.

Powielenie $\mathrm{w}$ umowie danego przepisu bezwzględnie obowiązującego jest oczywiście dopuszczalne i w praktyce często stosowane. Nawet dokonanie tego, jak w analizowanym przypadku, w sposób niedosłowny skutkujący próbą zawężenia zakresu przepisu ius cogens nie musi wiązać się ze stwierdzeniem nieważności takiego zastrzeżenia. Nic nie stoi bowiem na przeszkodzie, żeby uznać, że np. obowiązek zachowania tajemnicy zawodowej obejmuje radców prawnych przez pierwsze 12 miesięcy na podstawie zarówno klauzuli stron, jak i u.r.p. i k.e.r.p., natomiast po tym okresie już tylko na mocy u.r.p. i k.e.r.p. Tak długo więc, jak niedosłowne powielenie

${ }^{11}$ Wyrok Sądu Apelacyjnego w Rzeszowie z dnia 15 maja 2014 r., I ACa 80/14, niepubl.

12 E. Łętowska, K. Osajda, Zbieg norm art. 58 i 3531, w: System prawa prywatnego, t. 1: Prawo cywilne - część ogólna, red. M. Safjan, Warszawa 2012, s. 650.

${ }^{13}$ Wyrok SN z dnia 9 lutego 2012 r., III CSK 181/11, „Orzecznictwo Sądu Najwyższego. Izba Cywilna” 2012, nr 7-8, poz. 101. 
przepisu bezwzględnie obowiązującego nie skutkuje sprzecznością z nim, nie można go podważać. Sytuacja zmienia się jednak, gdy towarzyszy temu zastrzeżenie dodatkowego wynagrodzenia. Określenie wynagrodzenia za zaniechanie, do którego radca prawny zobowiązany jest już na mocy przepisów bezwzględnie obowiązujących, powoduje, że przysporzenie faktycznie jest pozbawione kauzy. Zastrzeżenie takiego obowiązku bowiem nie wpływa na sytuację prawną podmiotu, w szczególności zaś nie może powodować zawężenia zakresu obowiązku nałożonego w drodze przepisu bezwzględnie obowiązującego. W przedmiotowej sprawie więc zastrzeżenie takie nie czyni w sferze obowiązku zachowania tajemnicy zawodowej przez radców prawnych żadnej zmiany, ponieważ został on już (jak wyżej wskazano, w znacznie szerszym wymiarze) nałożony w u.r.p. i k.e.r.p. W gruncie rzeczy więc radcowie prawni mieliby otrzymywać wynagrodzenie niejako za nic. Według utrwalonej linii orzeczniczej ${ }^{14}$, brak kauzy czynności przysparzającej stanowi podstawę uznania jej za nieważną $z$ powodu niezgodności $z$ zasadami współżycia społecznego. Artykuł 410 § 2 k.c. pozwala uzyskane w taki sposób świadczenie uznać za nienależne $\mathrm{w}$ związku $\mathrm{z}$ nieważności czynności prawnej, która do niego zobowiązywała. Zgodnie natomiast $z$ art. 405 k.c. w zw. $z$ art. 410 § 1 i 2 k.c., w przypadku uzyskania w ten sposób przysporzenia, aktualizuje się obowiązek wydania go w naturze lub zwrotu wartości.

Należy zwrócić uwagę również na występującą u stron asymetrię informacji. Radcowie prawni musieli mieć doskonałą świadomość ciążących na nich obowiązków, a zatem i bezpodstawności dodatkowej gratyfikacji. Spółka natomiast nie zdawała sobie z tego sprawy, co zostało wykorzystane przez powodów i stanowi dodatkowy argument za uznaniem klauzuli za niezgodną z zasadami współżcia społecznego.

Wywody Sądu Najwyższego w zakresie, w jakim odnoszą się do tajemnicy zawodowej radców prawnych, nie budzą więc zastrzeżeń. Warto jednak zauważyć, że treść klauzuli nie sprowadzała się

${ }^{14}$ Wyrok Sądu Apelacyjnego w Poznaniu z dnia 21 marca 2007 r., I ACa 1136/06, niepubl.; wyrok Sądu Apelacyjnego w Poznaniu z dnia 21 maja 2008 r., I ACa 298/08, niepubl.; wyrok Sądu Apelacyjnego w Szczecinie z dnia 6 marca 2013 r., I ACa 779/12, niepubl. 
tylko do tego zagadnienia. Obejmowała ona bowiem także zakaz konkurencji zdefiniowany szeroko, oznaczający m.in. wykonywanie wszelkich czynności w ramach stosunku pracy lub jakiegokolwiek innego stosunku prawnego na rzecz jakichkolwiek polskich i zagranicznych podmiotów konkurencyjnych względem spółki. Kwestia niezgodności z zasadami współżycia społecznego tej części klauzuli budzi już wątpliwości.

\section{Problem działalności konkurencyjnej}

Znamienne, że ani u.r.p., ani k.e.r.p. nie odnosi się do pojęcia podmiotu konkurencyjnego czy działalności konkurencyjnej. Przepis art. 8 k.e.r.p. powołuje się jedynie na konflikt interesów, którego unikanie określa jako jeden $\mathrm{z}$ podstawowych obowiązków radcy prawnego. Pojęcie to zostało zdefiniowane w art. 21 k.e.r.p., zgodnie $z$ którym konflikt interesów zachodzi, gdy radca prawny zobowiązany jest do działania w interesie dwóch lub większej liczby klientów w zakresie tych samych lub związanych ze sobą spraw, a obowiązki te stoją ze sobą w sprzeczności lub istnieje znaczne ryzyko, że mogłyby one stać ze sobą w sprzeczności, oraz gdy radca prawny ma obowiązek działania w interesie klienta w danej sprawie, a obowiązek ten stoi w sprzeczności lub istnieje znaczne ryzyko, że mógłby stać w sprzeczności $z$ interesem radcy prawnego w tej sprawie lub w sprawie $z$ nią związanej. Podejmując próbę zdefiniowania podmiotów konkurencyjnych, skoro jak wskazał w uzasadnieniu SN, klauzula stron była wzorowana na art. 1011 k.p. ${ }^{15}$, można za Michałem Skąpskim ${ }^{16}$ odnieść się do ekonomicznego rozumienia pojęcia konkurencji określanej jako kierowanie podobnej oferty (produktów, usług) do tej samej grupy adresatów. Istotą konkurencji jest zatem alternatywny charakter wytworów konkurujących

${ }^{15}$ Ustawa z dnia 26 czerwca 1974 r. Kodeks Pracy, Dz.U. z 2017 r., poz. 60 ze $\mathrm{zm}$.

${ }^{16}$ M. Skąpski, Art. 101[1], w: Kodeks pracy. Komentarz, wyd. III, red. K. Baran, Warszawa 2016, https://sip.lex.pl/\#/komentarz/587329144/490777 (dostęp: 17.07.2017 r.). 
podmiotów. Obejmuje podmioty o choć częściowo pokrywającym się zakresie działalności. Wydaje się więc, że konflikt interesów zachodzi in concreto, natomiast podmioty są konkurencyjne względem siebie in abstracto. Wynika $z$ tego niezbicie, że obowiązek unikania konfliktu interesów nie jest tożsamy z zakazem świadczenia usług prawnych na rzecz podmiotów konkurencyjnych.

Podobny wniosek można odnaleźć w piśmiennictwie. Paweł Skuczyński ${ }^{17}$ wyraźnie podkreśla, że wykonywanie czynności na rzecz klienta będącego rynkowym konkurentem innego klienta jest typowym przykładem sprzeczności interesów, a nie ich konfliktu. Pojęcia te postuluje zdecydowanie odróżnić, argumentując, że sprzeczność interesów jest tylko sytuacją wyjściową, która dopiero może, ale nie musi przerodzić się $\mathrm{w}$ konflikt. $\mathrm{W}$ takich przypadkach radca prawny ma prawo, ale nie obowiązek unikania owej sprzeczności. Należy więc zważyć, że w przedmiotowej sprawie zastosowana przez strony klauzula spowodowała przeistoczenie dobrowolnej możliwości w bezwzględny obowiązek, zatem w tym zakresie nie stanowiła odwzorowania treści k.e.r.p.

Zgodnie $z$ art. 16 k.e.r.p. radca prawny nie może wykonywać czynności zawodowych na rzecz jakiegokolwiek podmiotu, o ile groziłoby to naruszeniem obowiązku dochowania tajemnicy zawodowej. Oznacza to, że warunkiem niemożności świadczenia usług prawnych jest zagrożenie niedotrzymania tajemnicy zawodowej. Niezależnie od tego, że tak sformułowana regulacja oznacza, że nawet tylko czysto hipotetyczny charakter naruszenia tajemnicy zawodowej już aktualizuje zakaz wykonywania czynności zawodowych, to zasadą wciąż jest możliwość ich wykonywania. Należy zważyć, że świadczenie usług prawniczych na rzecz podmiotów konkurencyjnych nie wiąże się koniecznie $z$ naruszeniem obowiązku zachowania tajemnicy zawodowej. Skoro k.e.r.p. wyłącza możliwość obsługi prawnej tylko w tym jednym szczególnym przypadku, a strony w swojej klauzuli zakazały tego w oderwaniu od tej przesłanki, przyjmując w zamian za warunek prowadzenie zdefiniowanej bardzo szeroko działalności konkurencyjnej, oznacza to, że poszły przynajmniej o krok dalej niż legislator. Ich postanowienie zatem nie powiela u.r.p. ani k.e.r.p.

17 P. Skuczyński, Konflikt interesów, w: Leksykon etyki prawniczej, s. 208. 
Warto zwrócić uwagę, że przestrzeganie obowiązku dotrzymania tajemnicy zawodowej nie jest jednoznaczne $z$ nieświadczeniem pracy dla podmiotów konkurencyjnych, w szczególności jeśli przyjęto szerokie rozumienie tego pojęcia. Możliwe jest bowiem wykonywanie takiej pracy w sposób lojalny, bez uszczerbku dla zaufania drugiej strony. Można zaryzykować stwierdzenie, że jest wręcz wskazane, by radcowie prawni obsługiwali podmioty prowadzące zbliżoną do siebie działalność, ponieważ sprzyja to specjalizacji radców prawnych oraz wpływa korzystnie na zrozumienie przez nich specyfiki danego typu działalności gospodarczej i problemów z nią związanych. Zasadnie zatem k.e.r.p. zakazuje tego tylko w przypadku ryzyka niedochowania tajemnicy zawodowej. Nic nie stoi jednak na przeszkodzie, by strony, korzystając $z$ zasady swobody umów (art. 3531 k.c.), ów rygor dobrowolnie zaostrzyły, umawiając się na swoistą wyłączność klienta w zakresie sektora gospodarki, w którym prowadzi działalność. W tym miejscu należy rozważyć jeszcze dopuszczalność zastrzeżenia $z$ tego tytułu dodatkowego wynagrodzenia. Wydaje się, że brak podstawy do wykluczenia takiej możliwości. Radcowie prawni, zobowiązując się do powstrzymywania od prowadzenia szeroko rozumianej działalności konkurencyjnej, zrezygnowali $z$ pewnej grupy potencjalnych klientów. Ograniczyli w ten sposób zakres odbiorców, do których kierują swoje usługi, co mogło, choć nie musiało, doprowadzić do zmniejszenia grona ich klientów, a tym samym i przychodów prowadzonej przez nich kancelarii. Mniejszy zysk radców prawnych jest więc hipotetyczny, jednak samo już podjęcie takiego ryzyka uzasadnia przyznanie im $z$ tego tytułu dodatkowego wynagrodzenia. Stanowi ono bowiem rodzaj rekompensaty za rezygnację z klientów, którzy potencjalnie byliby w zasięgu świadczonych przez nich usług. Okoliczność ta przesądza o ekwiwalentności świadczeń stron w tej części klauzuli.

\section{Wnioski}

Dla oceny trafności tezy sformułowanej przez Sąd Najwyższy decydujący jest fakt, iż odnosząc się wyłącznie do obowiązku zachowania tajemnicy zawodowej, stanowi pewne uproszczenie. Nie oddaje ona 
całości rozważań i wniosków zawartych w uzasadnieniu. Należy zwrócić uwagę, że odnosi się tylko do części zawartych w klauzuli regulacji, zatem nie odzwierciedla wiernie stanu faktycznego. W oderwaniu od niego więc nie można jej nic zarzucić. Jest słuszna. Pochylając się jednak dokładniej nad analizowanym przypadkiem, należy dojść do wniosku, że stwierdzenie nieważności w związku z niezgodnością z zasadami współżycia społecznego klauzuli zastosowanej przez strony było zasadne tylko w zakresie, w jakim odnosiła się ona do obowiązku zachowania tajemnicy zawodowej, natomiast w odniesieniu do zakazu konkurencji wydaje się bezpodstawne. Analiza klauzuli przez pryzmat tylko jej części wywołała skutki dla niej niweczące. Dokonanie jej podziału i rozpatrzenie elementów składowych z osobna wsparłoby konsekwencję wywodu. W efekcie należałoby stwierdzić nieważność tylko jednego $z$ elementów klauzuli przy jednoczesnym stosownym obniżeniu wynagrodzenia w związku ze zmniejszeniem jej zakresu.

Trudno jednak przecenić praktyczne znaczenie przytoczonej tezy. Sąd Najwyższy słusznie zapobiegł rozprzestrzenieniu się niezdrowej tendencji i przekształceniu jej w stałą praktykę. Tak wyraźne nadużycie pokładanej przez spółkę wiary w lojalność zawodów zaufania publicznego zasługuje na piętnowanie. Niemniej sąd dopuścił się pewnego uproszczenia, stwierdzając nieważność również postanowienia, które nie powielało, ale rozszerzało ustawową regulację, wskutek czego wyrok należy uznać za częściowo słuszny i potrzebny, a częściowo zbyt daleko idący.

\section{STRESZCZENIE}

Klauzula zasad współżycia społecznego w umowie o obsługę prawną - glosa do wyroku Sądu Najwyższego z dnia 19 czerwca 2015 r., IV CSK 590/14

Glosa odnosi się do przypadku, w którym strony (spółka i radcowie prawni) zawarli umowę, która zawierała zastrzeżenie dodatkowego wynagrodzenia za utrzymanie $\mathrm{w}$ tajemnicy wszelkich informacji uzyskanych podczas pełnienia obsługi prawnej oraz za powstrzymywanie się od sprawowania obsługi prawnej na rzecz innych spółek konkurencyjnych. Według autorki 
wywód Sądu Najwyższego w zakresie to tajemnicy zawodowej jest zasadny. Autorka jednak uwzględnia również drugi aspekt zastrzeżenia zawartego w umowie stron - powstrzymywanie się od sprawowania obsługi prawnej na rzecz innych spółek konkurencyjnych. Wskazuje, że żadna z relewantnych regulacji nie odnosi się do pojęcia podmiotów konkurencyjnych, co pozwala podważyć wywód Sądu Najwyższego w tym zakresie.

Słowa klucze: zasady współżycia społecznego; umowa o obsługę prawną; tajemnica zawodowa; konkurencja

\section{SUMMARY}

Principles of community life in legal service agreement gloss to sentence of the Supreme Court of $19^{\text {th }}$ of June 2015, IV CSK 590/14

The gloss relates to a case in which that parties (company and solicitors) have concluded a legal service agreement included a reservation of additional compensation for misprision any information gained while providing legal service and for refraining from providing legal service for other competitive companies. According to an author, the dilitation of The Supreme Court with regard to the professional secret is righteous. The author, however, takes into consideration also other aspect of reservation of the agreement - refraining from providing legal service for other competency companies. She indicates that none of relevant regulations define the notion "competitive entities", what enables to challenge the conclusion of the Supreme Court within this extent.

Keywords: principles of community life; legal service agreement; professional secret; competition

\section{BIBLIOGRAFIA}

Kodeks pracy. Komentarz, wyd. III, red. K. Baran, Warszawa 2016.

Kodeks cywilny. Komentarz. Część ogólna, red. P. Księżak, M. Pyziak-Szafnicka, Warszawa 2014.

System prawa prywatnego, t. 1: Prawo cywilne - część ogólna, red. M. Safjan, Warszawa 2012.

Leksykon etyki prawniczej, red. S. Sykuna, P. Skuczyński, Warszawa 2013. 
